\title{
The Digital Dimension of Mobilities: Mapping Spatial Relationships between Corporeal and Digital Displacements in Barcelona
}

\author{
Fiammetta Brandajs
}

Citation: Brandajs, F. The Digital Dimension of Mobilities: Mapping Spatial Relationships between Corporeal and Digital Displacements in Barcelona. Information 2021, 12, 421 https://doi.org/10.3390/info12100421

Academic Editor: Adel Ben Youssef

Received: 5 September 2021

Accepted: 8 October 2021

Published: 15 October 2021

Publisher's Note: MDPI stays neutral with regard to jurisdictional claims in published maps and institutional affiliations.

Copyright: (C) 2021 by the author. Licensee MDPI, Basel, Switzerland. This article is an open access article distributed under the terms and conditions of the Creative Commons Attribution (CC BY) license (https:/ / creativecommons.org/licenses/by/ $4.0 /)$.
Faculty of Tourism and Geography, Rovira I Virgili University, 43003 Tarragona, Spain; fiammetta.brandajs@urv.cat

\begin{abstract}
This paper explores the ways in which technologies reshape everyday activities, adopting a mobility perspective of the digital environment, which is reframed in terms of the constitutive/substitutive element of corporeal mobility. We propose the construction of a Digital Mobility Index, quantified by measuring the usage typology in which the technology is employed to enable mobility. Through a digital perspective on mobilities, it is possible to investigate how embodied practices and experiences of different modes of physical or virtual displacements are facilitated and emerge through technologies. The role of technologies in facilitating the anchoring of mobilities, transporting the tangible and intangible flow of goods, and in mediating social relations through space and time is emphasized through analysis of how digital usage can reproduce models typical of the neoliberal city, the effects of which in terms of spatial (in)justice have been widely discussed in the literature. The polarization inherent to the digital divide has been characterized by a separation between what has been called the "space of flows" (well connected, mobile, and offering more opportunities) and the "space of places" (poorly connected, fixed, and isolated). This digital divide indeed takes many forms, including divisions between classes, urban locations, and national spaces. By mapping "hyper- and hypo-mobilized" territories in Barcelona, this paper examines two main dimensions of digital inequality, on the one hand identifying the usage of the technological and digital in terms of the capacity to reach services and places, and on the other, measuring the territorial demographic and economic propensity to access to ICT as a predictive insight into the geographies of the social gap which emerge at municipal level. This approach complements conventional data sources such as municipal statistics and the digital divide enquiry conducted in Barcelona into the underlying digital capacities of the city and the digital skills of the population.
\end{abstract}

Keywords: mobilities; immobilities; digital divide; technology; COVID-19

\section{Introduction}

The term digital mobility is used to label the bundling of transportation services to users through information technology platforms. However, when we talk about digital mobility, we are also talking about what is behind the use of technology, i.e., access to it. It would be almost unthinkable to discuss the mobility of cities without addressing the digital issue. It is also clear that technology has a leading role in the design, planning, and operability of all the mobility systems of tomorrow. The way in which users interact with those systems is critical to potentiate the "right" combination of mobility solutions that will create the right balance of, among other dimensions, social inclusion, and the universality of access to all systems. The sustainability concept, together with the digital transformation of society, marks the tipping point toward the identification of new directions and possibilities that in the past were impossible to consider. It is therefore key to refer to the issue of the "digital divide", even if this is a controversial and much discussed term [1,2], which describes a gap in terms of access to and usage of information and communication technology. This gap refers to the inequality between people who have access to and knowledge 
of new technologies and those who do not. This term also refers to the differences between groups according to their ability to use ICTs skillfully. The OECD [3] (p. 5) defines the "digital divide" as "the gap between individuals, households, businesses and geographical areas at different socio-economic levels with regard to both their opportunities to access ICTs and their use of the Internet for a wide variety of activities". Nevertheless, within this context, numerous studies in the last decade have addressed the need to detect, measure, and understand the differences between a society having accessibility and/or its use of the technology $[4,5]$.

To investigate the "digital divide" in its mobile dimension, which includes the networks and technologies that support and empower subjects to move, we refer to the theoretical framework of the mobilities paradigm which in the last 20 years took central stage in social sciences as toolbox for the study of society. Following the path opened by John Urry and Tim Cresswell in different works e.g., [6,7], mobilities also produced a fundamental repositioning of the Science and technology studies field, which, has come to occupy a key role in the analysis of the mobile society and more broadly in the study of the social inequalities across disciplinary entrenchments. Specifically, we refer to the concept of "motility" introduced by Kaufmann et al. [8] (p. 749) "that conceives of spatial and social mobility as indicants of a more comprehensive form of mobility that is not limited to actual or past displacements". Motility can be defined as the capacity of entities (i.e., goods, information, or persons) to be mobile in social and geographic space, or as the way in which entities access and appropriate the capacity for socio-spatial mobility according to their circumstances (p. 750). Translating this concept to what it means in the field of digital, we could then talk about "digital motility" as the propensity for movement trough and within digital spaces, considering access to digital as a precondition to move both physically and virtually, transcending geographical and social distance to maintain those interconnections which are central to developing a complex relations system giving steady access to our networked society. It is a matter of investigating the degree of autonomy that subjects have to express their own possibilities for action with the digital environment by analyzing the potential daily restrictions on freedom linked to the lack of adequate infrastructure or physical tools and personal skills.

The potential mobility, therefore, aside from the multiplicity of interpretations analyzed in the literature It implies here, "at least implicitly, that human potential moving through natural means, that is walking and running, is similar in its basic nature to the human ability to move through most powerful man-made technologies" [9] (p. 172).

Recently, the literature has emphasized the complex interdependencies between corporeal and digital mobilities e.g., [10-13]. Various types of mobilities are said to make up a complex mobility system, and by studying this system it would be possible to better understand people's needs for traveling in contemporary societies in which daily undertakings, such as work and leisure activities, are spatially dispersed. Independently, the growing body of research on ICT has analyzed how information and communication technologies affect the formation of social networks, in particular, and social interaction, in general e.g., [14-17]. Combining these ontological structures to investigate the digital divide means looking at mobilities as tightly knit with digital technology; not only as enabling infrastructure for large-scale human mobilities, but also as agency and a device that structures the connections (which may be physical, mental, social and financial) that drive them [18], and which are responsible for generating new digital geographies (both social and economic). According to Shelton et al. [19], these geographies are not at all "technologically determined". Rather, how places and people are connected (or remain offline) still depends on patterns historically rooted in financial constraints and cultural and social transformations or evolutions. As highlighted by this author, these new geographies have the power to be immensely "empowering" (for the people and places capable of developing and consuming them) and, at the same time, dangerously dominant as institutional and governmental forces capable of maximizing the power of information with increasing customization and spatial and geographical specificity. 
The new institutional regime identified by Boltanski and Chiapello [20,21] is the power in advanced capitalism based on flexibility, ingenuity, adaptability, speed, and weightlessness. The skills to navigate the turbulent high strata of the global economy with its demands for multi-tasking across space, time, and networks is "the capacity to learn and adapt to new functions, to gain trust, to communicate, to relate". How digital technologies are interwoven with "mobile lives" becomes not merely a question that addresses novel forms of transportation and travel but one which is fundamentally reframed in terms of capacities for movement in a broader sense and which, as we have seen, nowadays means having access to capital in all its aspects. In other words, if social relations, capital, or resources nuance specific spatialities, then access to-or appropriation of-such capital rests on mobilities, which in turn require the disposition of certain resources, such as economic capital, and the necessary knowledge, capacities, and skills [22].

The ways in which technologies reshape everyday activities and interpersonal relations, as well as connections with others and connections with the wider world, provides a predictive insight into the geographies of the social gap which emerge at territorial level by mapping out "hyper-mobilized" territories rich in technological components that contrast with others that are poor in functions and little considered by both public administrations and private investments. Interstitial territories, those that remain outside the network, become marginal areas. This has become increasingly topical with the outbreak of COVID-19, as physical immobility has strongly fostered virtual mobility, revealing a wide disparity among populations in which those with higher income are able to access technology that can ensure work continues digitally during social isolation. Against this background, modern societies around the globe have developed hectic routines to accelerate and propel the digitalization of work, leisure, and interaction in general; "digital mobilities" have become the new normal [23]. Concepts already adopted in the theorization of "network capital" [24] conceive of both mobility and immobility as forms of power, if up to the individual. The distribution of the capacities for potential movement or non- movement in relation to the physical, social, and political possibilities that surround us is therefore unequal. Consequently, analyzing the digital environment by focusing on the mobilities it generates means exploring the processes of the reproduction, redistribution, or exclusion of wealth and power.

This paper is organized as follows. Section 2 describes the main statistical and geoanalytic methods for the construction of indexes used in our research are situated in the broader framework of socio-spatial studies and the mobilities literature. In parallel, a second part clarifies the mobile dimensions of digital and its theoretical underpinnings. Section 3 then combines the results from the individual statistical steps. Finally, Section 4 and 5 presents our discussion and conclusions.

\section{Materials and Methods}

The process of obtaining a meaningful picture of the urban digital context involved a sequence of four main operations: the construction of a composite index of the mobile dimension of digital; the creation of a second synthetic index by including key variables which define the underlying socio-demographic structure of digital development; analysis of the spatial deployment of new mobility systems to identify, delimit, and quantify spatial patterns of distribution in Barcelona city (Table 1); finally, a focus on the resulting interdependencies between corporeal and digital mobilities/immobilities.

The attempt to analyze the digital disparities within the municipal boundaries of Barcelona is based on the analysis of the synthetic index, which evaluates both trends in citizens' usage of technological and digital services and access to the services spread over the municipal territory. Some studies account for differences in usage by grouping Internet users into use typologies e.g., [25-27]. These studies utilize descriptive and inductive research to identify categories of usage types [28]. In addition, the differences can be explored in terms of the relevance of the information and services to users [29]. Here, however, the specific aim is to measure the level of mobility involved in "virtually" 
reaching services, people, or places. This methodology responds to the need to consider the digitalization of the territory from the perspective of mobility and its multidimensionality, and therefore includes the main thematic fields of interaction with technology and the ways in which citizens operate in the digital environment.

Table 1. Synthetic indexes conceptual framework.

\begin{tabular}{|c|c|c|c|c|c|c|c|c|}
\hline $\begin{array}{l}\text { Mobility } \\
\text { Field }\end{array}$ & $\begin{array}{l}\text { Synthetic } \\
\text { Indexes }\end{array}$ & Variables & Ranking & $\begin{array}{c}1 \\
\text { Synthetic } \\
\text { Index }\end{array}$ & $\begin{array}{l}\text { Background } \\
\text { Field }\end{array}$ & Variables & $\begin{array}{c}2 \\
\text { Synthetic } \\
\text { Index }\end{array}$ & $\begin{array}{c}\text { Smart } \\
\text { Mobility } \\
\text { Services } \\
\text { Spatial } \\
\text { Deployment }\end{array}$ \\
\hline \multirow{3}{*}{$\begin{array}{l}\text { Social life } \\
\text { mobility }\end{array}$} & \multirow{3}{*}{$\begin{array}{c}\text { Remote } \\
\text { communication }\end{array}$} & emailing & \multirow{3}{*}{$\begin{array}{c}\text { Remote } \\
\text { Communica- } \\
\text { tion } \\
\text { Rank }\end{array}$} & \multirow{13}{*}{ 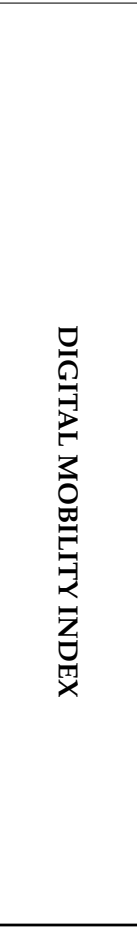 } & \multirow{4}{*}{ Economic } & \multirow{4}{*}{$\begin{array}{l}\text { Average } \\
\text { personal net } \\
\text { income }\end{array}$} & \multirow{13}{*}{ 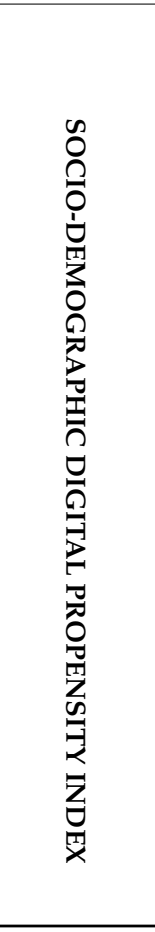 } & \multirow{13}{*}{ 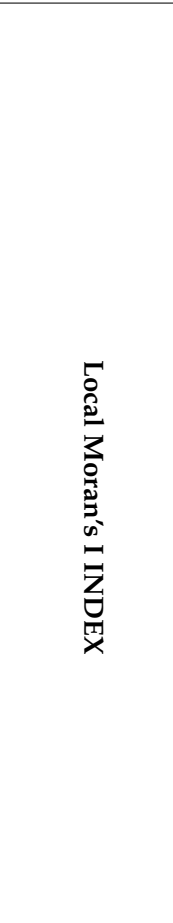 } \\
\hline & & $\begin{array}{l}\text { Video com- } \\
\text { munication }\end{array}$ & & & & & & \\
\hline & & $\begin{array}{c}\text { Social } \\
\text { networking }\end{array}$ & & & & & & \\
\hline \multirow{2}{*}{$\begin{array}{l}\text { Content and } \\
\text { innovation } \\
\text { mobility }\end{array}$} & \multirow{2}{*}{$\begin{array}{c}\text { ICT } \\
\text { Dynamization }\end{array}$} & $\begin{array}{l}\text { Content } \\
\text { creation }\end{array}$ & \multirow{2}{*}{$\begin{array}{c}\text { ICT Dy- } \\
\text { namization } \\
\text { Rank }\end{array}$} & & & & & \\
\hline & & $\begin{array}{l}\text { ICT develop- } \\
\text { ment }\end{array}$ & & & \multirow{4}{*}{ Education } & \multirow{4}{*}{$\begin{array}{l}\text { Tertiary } \\
\text { graduation } \\
\text { rate }\end{array}$} & & \\
\hline \multirow{6}{*}{$\begin{array}{l}\text { Everyday } \\
\text { mobility }\end{array}$} & \multirow{6}{*}{ Services access } & $\begin{array}{c}\text { General } \\
\text { information }\end{array}$ & \multirow{6}{*}{$\begin{array}{c}\text { Services } \\
\text { Access Rank }\end{array}$} & & & & & \\
\hline & & $\begin{array}{c}\text { Specific } \\
\text { information }\end{array}$ & & & & & & \\
\hline & & $\begin{array}{c}\text { Economic } \\
\text { transaction }\end{array}$ & & & & & & \\
\hline & & $\begin{array}{l}\text { Administrative } \\
\text { procedures }\end{array}$ & & & \multirow{3}{*}{$\begin{array}{c}\text { Active } \\
\text { population }\end{array}$} & \multirow{3}{*}{$\begin{array}{l}\text { Young and } \\
\text { middle-aged } \\
\text { adults rate }\end{array}$} & & \\
\hline & & $\begin{array}{l}\text { Education } \\
\text { opportuni- } \\
\text { ties }\end{array}$ & & & & & & \\
\hline & & $\begin{array}{l}\text { Labour op- } \\
\text { portunities }\end{array}$ & & & & & & \\
\hline \multirow[b]{2}{*}{$\begin{array}{c}\text { Social } \\
\text { engagement } \\
\text { mobility }\end{array}$} & \multirow[b]{2}{*}{$\begin{array}{c}\text { Citizen } \\
\text { participation }\end{array}$} & Services offer & \multirow[b]{2}{*}{$\begin{array}{c}\text { Citizen } \\
\text { Participation } \\
\text { Rank }\end{array}$} & & \multirow[b]{2}{*}{$\begin{array}{l}\text { Migration } \\
\text { flows }\end{array}$} & \multirow{2}{*}{$\begin{array}{l}\text { Foreign } \\
\text { population } \\
\text { rate }\end{array}$} & & \\
\hline & & $\begin{array}{c}\text { Community } \\
\text { participation }\end{array}$ & & & & & & \\
\hline
\end{tabular}

The Digital Mobility Index has been developed by constructing a series of partial indicators with the same unit of measurement (percentages) to quantify the results of the digital divide enquiry conducted in Barcelona [30]. The different types of use of the available technology, such as remote communication or access to services, etc. (proceeding from the enquiry), have been classified as diverse forms of virtual mobility (Table 1), which consequently pool the variables in sets of indexes weight assigned to the variables reflects an a priori weighting scheme based on complexity and the level of knowledge required to access the different services.

All the parameters are connected in a single index called the Digital Mobility Index, which is formulated according to the following expression:

$$
\mathrm{DMI}=\sum_{i=1}^{n} \text { Wi }{ }^{2} / \sum_{i=1}^{n} \eta i
$$

where $W j$ is the partial index and $\eta j$ is the corresponding weight.

The design of the synthetic index Digital Mobility Index (DMI) takes into account four dimensions of digital mobility (Table 1). The mobility fields, which are detailed below, are categorized into: social life mobility (leisure, entertainment and social activities); content and innovation mobility (content creation and digital development); everyday mobility (administration, transactions and services-related activities); social engagement mobility (voluntary work and charity). 


\subsection{Social Life Mobility}

How the spatialities of social life are produced by new technologies presupposes "both the actual and the imagined movement of people from place to place, event to event, new forms of coordination of people, meetings and events e.g., [12,31,32], and a rearrangement of the relations between domestic and public space" $[12,33]$. The most evident expression of a new and generalized type of behavior emerging in social life and mediated by technology is represented on the one hand by the on-the-move "micro-coordination" of daily activities and on the other by the complete substitution of physical encounters with virtual ones. In this field of research, Townsend [34] analyzes the mobility patterns of adolescents in countries around the world with high levels of mobile phone ownership. Instead of meeting in public places such as squares or street corners, young people tend to coordinate movements and meetings "in itinere" through instantaneous communication via mobile phones. This type of experiment opens the debate on the long-term effects of the transformation of the ways in which people meet and interact in public space and actually leads us to what Lanier [35] calls "cybernetic totalitarianism", in which individuals are channeled and trained to be "users" of a "cybernetic mechanism", with its built-in categories of interaction and algorithms that reinforce mass culture by creating increasingly closed bubbles and relational circles through involuntary virtual segregation. That said, social life appears to expand and be capable of crossing borders near and far, allowing social ties to be remotely tended to through a networked model.

On the one hand, a social mobility produced, fed, and accelerated by the digital environment of mobile applications stands out; and on the other, the virtual sociality of media platforms, social networks, and whole e-communication systems which enable static global relations-which do, however, contribute to the multiplication of future movements and displacements-is highlighted. This index is therefore useful not only to argue the extent of decentralized interactions in the hyper-connected global system enabled by technologies, but also to frame those who employ it mostly for social movement and the type of encounters that they may cause or inhibit.

\subsection{Content and Innovation Mobility}

The variables of this index investigate the capacity of the territory to mobilize and spread intellectual and technical knowledge, on one hand reflecting the increasingly deterritorialized online items which, even if inhabited by "territorialized" users, can easily cross borders and distribute content to audiences on a transnational scale [36,37], enhancing the digital mobility of media content across countries and regions; and on the other, determining the relationships between the mobilities of ideas, skills, knowledge, production, and art against the increasingly ubiquitous mobility of virtual bodies, driven by the expanding technological capabilities and performance of digital platforms; the bodies being produced or "permitted" by technological innovation itself. The media (individual, corporate, or public) power distribution enables digital workflows through products and services that empower territories to create, manage, deliver, and monetize digital content. Indeed, the literature on the digital divide also invites us to consider that digital inequality is more important for production than for consumption. However, some Internet theorists argue that digital cultural production is outside the structure of political systems e.g., [38-40]; multiple studies, for instance, have examined to what degree socio-economic status is associated with one's ability to create information online [41,42], demonstrating that digital inequality is still partially tied to status stratification $[27,43,44]$.

This index expects to measure the volume of human capital related to digital content creation by ranking the capacity of the city's territories to generate and mobilize knowledge and innovation through digital media.

\subsection{Everyday Mobility}

The digitization of our everyday life has already led to a change in mobility terms. Currently, while some transactions can indeed be fully processed and concluded online, 
others still require a physical movement despite allowing the digital transaction. Lastly, some generate new urban movements to add to those that already exist. Therefore, while virtual structures play a highly significant role in re-establishing patterns of mobility by enhancing it for those who can reach these places exclusively virtually, or through preliminary contact online, thus highlighting the power shift toward the digital user, the emphasis is otherwise on the potential savings from the physical mobility that comes with services and everyday tasks.

The index equally covers the use of ICT and its implementation by the "e-government" to provide information and public services to the community-citizens, businesses, governments (other governments and public agencies), and employees [45] — as well as the use of online services in the private sector (financial activities, renting, e-shops, etc ... ).

\subsection{Social Engagement Mobility}

On the ground, the everyday issues faced by digital include the engagement and participation of citizens, consumers, and workers in the public and political, cultural, and economic spheres of the Internet. Digital Equity is defined as the condition in which all individuals and communities have the information technology capacity needed for full participation in our society, democracy, and economy, but is also necessary for civic participation. The evolution of digital social engagement is concerned with the social environment and plays a critical role in the community, with expansive, reflexive, durable, and exponential effects across space and time [46] and effects on the mobility of that community's older adults as they age.

\subsection{Smart Mobility}

The Digital Mobility Index has been calculated at a neighborhood scale, however, to attain a finer and more detailed view of the phenomena investigated. The socio-demographic and spatial deployment of smart mobility services analyses have both been conducted at census section level. To measure the distribution of the services and assign a value to all the census sections, a spatial analysis point features (mobility systems) has been carried out, allowing us to identify where point clustering is unusually (statistically significant) intense or sparse by applying "Anselin Local Moran's I statistic", as well as "statistically significant hot spots, cold spots, and spatial outliers" in order to identify different patterns of distribution (map 1). The spatial component of the territorial distribution of the provision of new mobility systems available in the urban territory, retrieved from the Smart City Strategic Plan 2014 [47], includes the service points for provision of the city bike system, charging stations for electric cars, smart parking spaces, and car sharing stations.

\subsection{Socio-Demographic Digital Propensity}

The Socio-Demographic Digital Propensity Index was developed to measure the level of potential access to ICT. The index takes into consideration the existence of an interrelationship between the use of technologies and the main socio-demographic variables addressed by the literature.

Thus, the related digital divide literature provides evidence on several socio-demographic variables which explain individual differences in Internet access and use in terms of income, level of education, type of household, age, and gender, e.g., [48], some of which have been used here to measure the territorial context in which citizens' digital skills are performed. Even though discrepancies in terms of physical access have diminished, significant differences may remain in terms of differential skills and the nature of Internet use e.g., [49-53]. Age appears to be one of the most significant variables that affect Internet use e.g., [54]. Most studies on digital usage suggest that education is the most important predictor for explaining the types of online activities a person will pursue [55]. Income is a variable with a strong correlation to the level of education attained. However, there are studies that show an independent effect of income on, for example, physical and material Internet access [56]. These three variables have been taken into account in building the Socio-Demographic Dig- 
ital Propensity Index as average personal net income, tertiary graduation rate, and young and middle-aged adult rate. As can be seen in Table 1, as well as these three variables, recognized as factors of influence in the use of ICT, the foreign population rate has been included as a variable of interest within the digital knowledge flows framework [57]. In approaching digital as a mobility tool, this is crucial considering the number of foreigners in the territory. While they may be mobile from the corporeal point of view, they are mobilized to an even greater extent by the volume and coverage of the connections generated within transnational migration networks, e.g., [58]. From a general perspective, digital deployment has a bidirectional influence on social phenomena such as migration processes. On the one hand, it extends the possibility of virtually connecting to and reaching the country of origin and helps migration networks to grow transnationally [58,59], and on the other, it encourages or discourages displacements to a specific destination. Several studies have also examined the transnational habits of migrants and the consumption of digital media among diaspora communities e.g., [60,61], arguing there is an increase in the digital mobility of transnational media content in areas with a high migrant population.

Finally, the research turns toward the analysis on the interdependencies between corporeal and digital mobilities/immobilities.

Digital space and practices are characterized, as we have seen, by an unequal geography with consequent socio-spatial and mobility implications that, as emphasized throughout this paper, are intrinsically linked to each other. While on the one hand we recognize, once again, the role of ICT and the technological infrastructure in facilitating the anchoring of mobilities to urban space, on the other hand we recognize that these technological anchors produce what Eliott and Urry term unforced "movement", namely the power to be able to move (or to be able to voluntarily stay still) as a major source of advantage. Elliott and Urry describe "network capital" as "a combination of capacities to be mobile, including appropriate documents, money, and qualifications; access to networks at-a-distance; physical capacities for movement; location-free information and contact points; access to communication devices and secure meeting places; access to vehicles and infrastructures; and time and other resources for coordination" [24] (p.10). Thus, to analyze the mutual interdependency between the digital and the physical by considering digital capabilities as a whole, as the most empowering element of both mobility and the "voluntary immobility" given by access to network capital, we reversed the question by focusing on the systems of mobilities that are required to enable immobilities. The analysis was carried out by exploiting the data of an experimental mobility study based on mobile phone data (part of the preparatory work for the 2021 Population and Housing Census) conducted by INE (National Institute of Statistics) during the COVID-19 lockdown.

\section{Results}

The map (Figure 1) identifies statistically significant high and low clusters (HH and LL) as well as high and low outliers (HL and LH), corrected by spatial dependence. The Anselin Local Moran's I (LISA, or cluster and outlier value analysis) identifies spatial clusters or groups of regions with similar values and spatial outlier values. This index calculates a value that represents the type of cluster for each entity: High-High (HH), Low-Low (LL), High-Low (HL) and Low-High (LH), as well as those that are not statistically significant.

As we can observe on the map, this demonstrates a dual reality. On the one hand, the most central area of the city, its eastward extension, and the north-west area display a pattern of distribution of the "smart" mobility systems per census section clustered as HighHigh, or in any case surrounded by other census sections with good infrastructure (LH). The situation changes completely in the census sections of the northern neighborhoods of the city, where a pattern is observed that presents some areas belonging to the High-Low type cluster, that is to say with a certain level of services related to mobility but nevertheless surrounded by low level census sections and where the Low-Low type census sections are very extensive. 


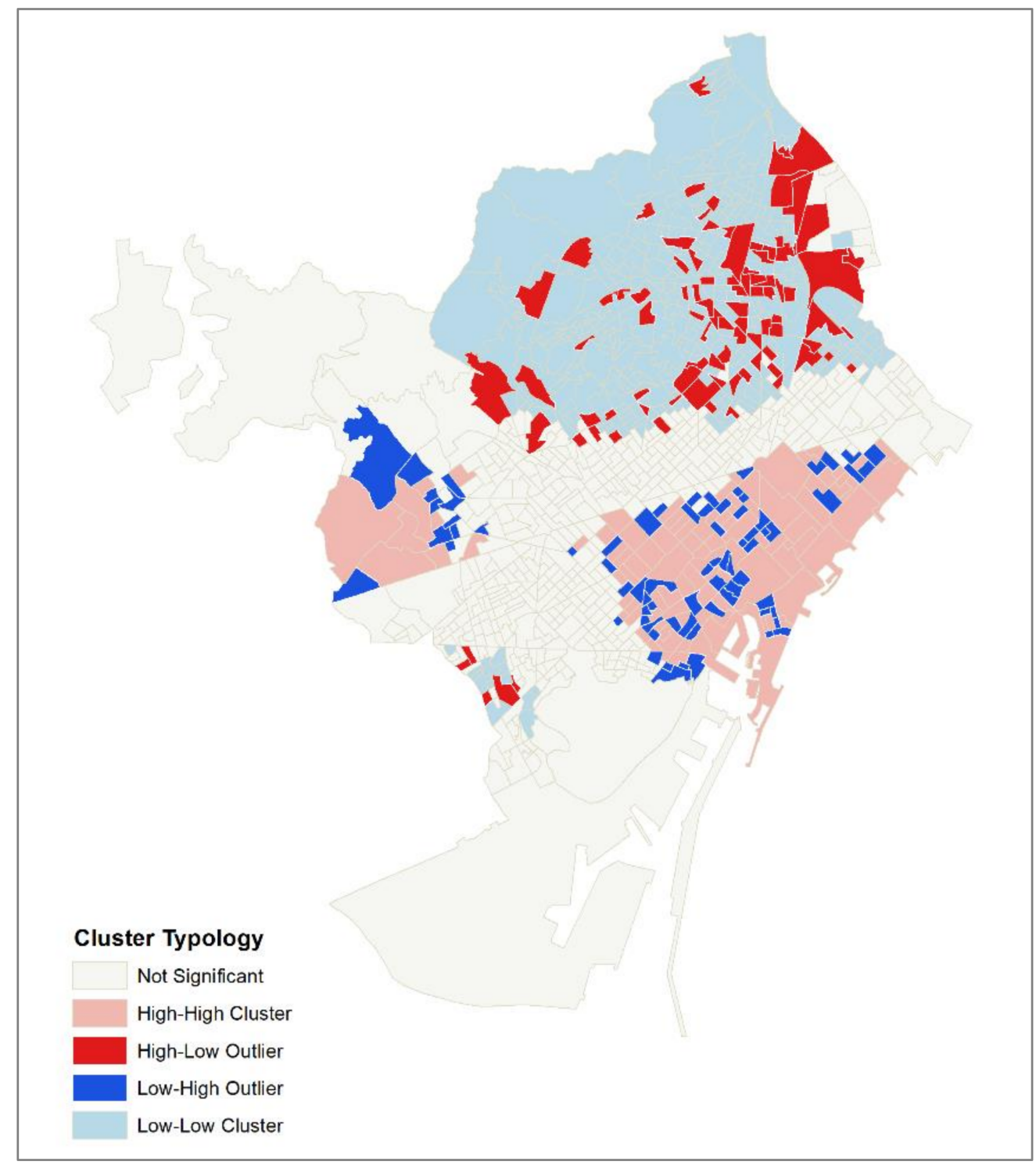

Figure 1. Smart mobility systems spatial distribution, Barcelona City.

The map 2 in Figure 2 shows a merging of the two synthetic indicators, DMI and SDPI, at dual territorial scale: neighborhood (DMI) and census section (SDPI). The SDPI synthetic index has been calculated within each class resulting from the Digital Mobility Index.

The map (Figure 2) reveals a certain territorial continuity that links the western sector to the east, with DMI values alternating between high and very high, from the area of Tibidabo i les Planes to Poblenou, supported by high SDPI values, especially evident in the areas of Pedralbes, in the north-western areas of Vallcarca, the right side of the Eixample (Eixample Dreta), and the Vila Olímpica neighborhood. The only anomaly interrupting this continuity concerns the area corresponding to Sant Gervasi, which has low SDPI values and medium DMI values. The correspondence of the maximum values of the Sant Martí District, including Vila Olímpica and the northernmost part of the Parc i la Llacuna del Poblenou, is certainly interesting, while the most peripheral part (east of the district) has intermediate DMI values and low SDPI values, suggesting that workers in the technology sector, the area of employment characteristic of the district, may come from other districts. This fact is supported by looking at map 3 (b) which situates the best ranking content and innovation development in the districts of Gràcia and Vallcarca as well as an enclave of Horta within a very disconnected territory, both from the point of view of mobility services 
themselves (map 1) as well as usage in the low-income neighborhoods of La Taixonera, Carmel Can Baró, and Ciudad Meridiana.

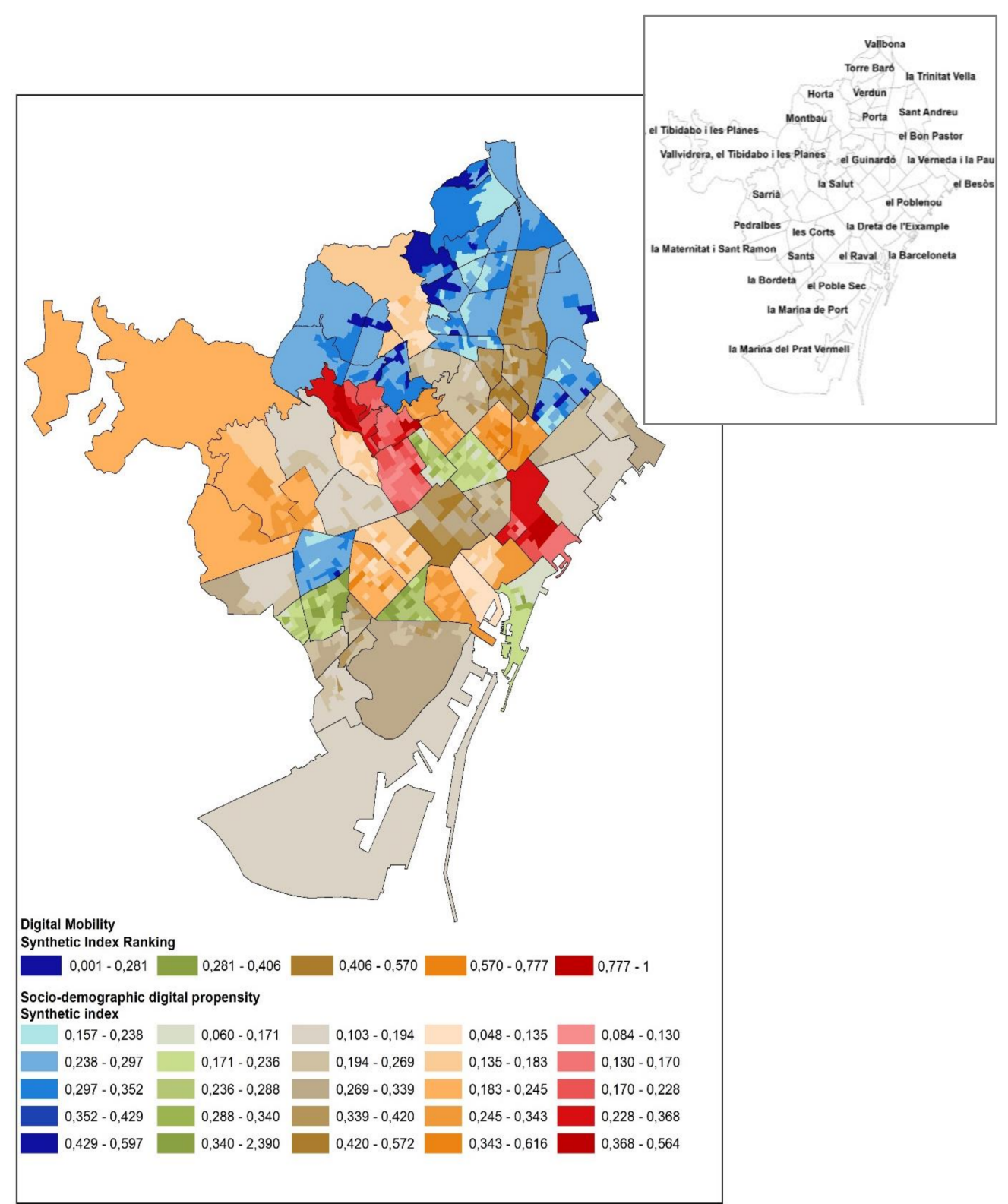

Figure 2. Digital Mobility Index and Socio-Demographic Digital Propensity, Barcelona City.

Indeed, the district of Sant Martí is still a fragmented territory in terms of its sociodemographic composition, since it includes neighborhoods historically known to be mostly low-income and working-class e.g., [62,63], and only part of the district has benefited from renewal. Under the umbrella of 22@, there are significant demographic and economic differences between territories divided by intangible boundaries. See, for example, the old neighborhoods of La Mina and La Verneda.

It is not surprising, therefore, that there are small areas with higher values for the Socio-Demographic Digital Propensity Index within the average value of the district for the Digital Mobility Index.

The values progressively decrease from the district of Sant Martí, including still medium-high values in the neighborhoods of Navas and Sant Andreu, which are indeed experiencing a certain renewal and demand due to being more accessible but centrally located neighborhoods. 
Finally, the neighborhoods of the Ciutat Vella district, the most cosmopolitan areas of the city that attract the most tourists, stand out with high DMI values supported by the general high SDPI value as expected due to a multiplicity of factors such as strong population renewal thanks to "globals" and the "mobile population" [24], who are skilled, networked, and have purchasing power; a mainly tourist-oriented economy that is currently technology-based (hospitality platforms, etc.); and the diffusion and ubiquitous availability of the Internet and digital services as shown in the spatial analysis (Figure 1).

Looking at the results of the partial indexes (Figure 3), a significant landscape emerges on the user profiles and habits unleashed by enabling digital services and where these are adapted to the different territories of the city.

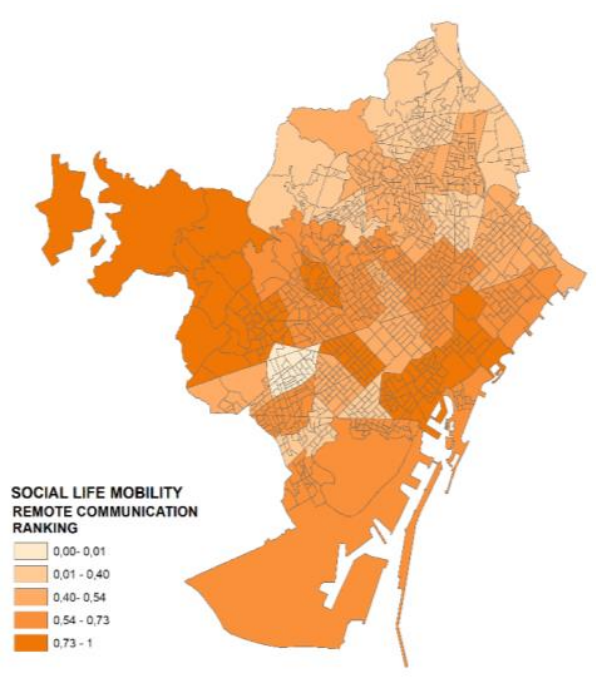

(a)

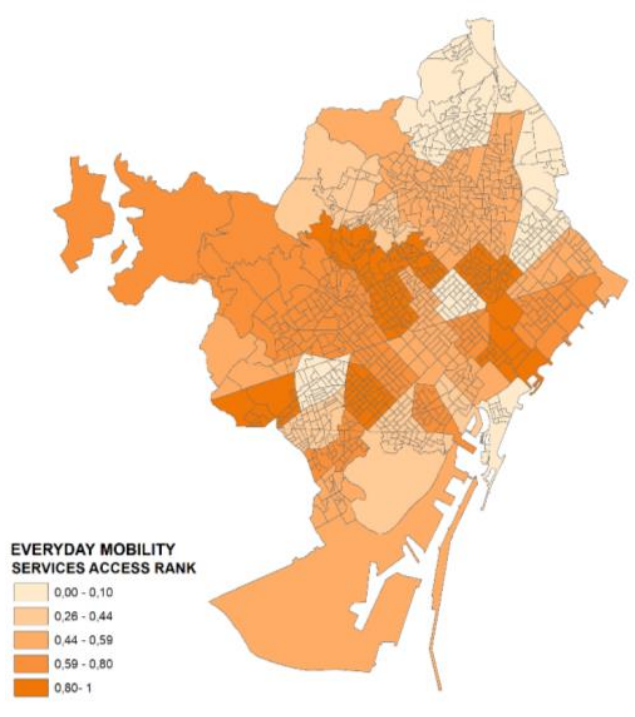

(c)

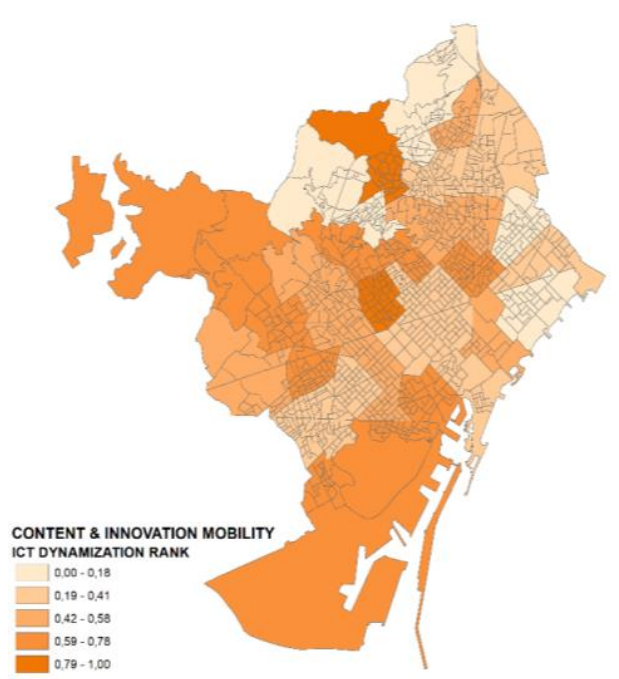

(b)

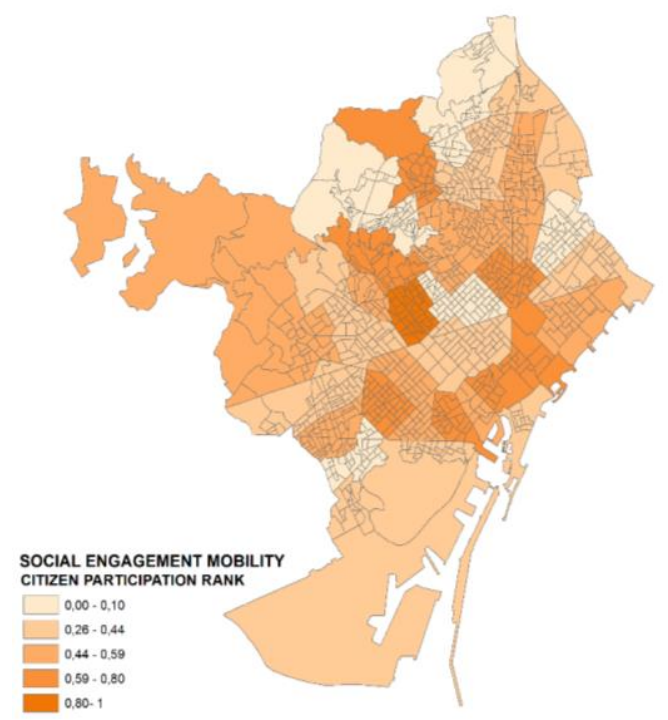

(d)

Figure 3. Digital Mobility by typology. (a) Synthetic index: Social life mobility; (b) Synthetic index: Content and innovation mobility; (c) Synthetic index: Every day mobility; (d) Synthetic index: Social engagement mobility, Barcelona City.

We observe some constants throughout the urban territory and neighborhoods that seem to have incorporated more than others the idea of mobility through the digital environment in a transversal way by encompassing all its variables. These include the vast area of the most privileged neighborhoods of the north-west axis, which (according to that 
described so far) are the best equipped and most active (Tibidabo i les Planes, Sarrià i Sant Gervasi, Bonanova, and Vila de Gràcia). In addition, the neighborhoods of Vila Olímpica, the northernmost part of Parc i la Llacuna del Poblenou and El Clot, as we have seen in the aggregate index, are among the most active in the network.

On the other hand, it is interesting to note the breakdown by typology, which indicates the specific needs of the urban populations living in the city's districts; see for instance, the correspondence between the areas of highest tourism and the central neighborhoods of the old town, which are currently inhabited by $43 \%$ of the foreign population [47]. The economic and social character of these neighborhoods implies the need to move globally both to attract tourist populations to the city and to keep the remote contacts of origin close. In addition, the dynamics of contact networks and social spheres are more extended at a global level and consequently have a very wide extra-territorial reach.

As far as mobility toward services is concerned, it is significant to note that the situation seems to be reversed for the neighborhoods of the old town (with the exception of Raval). On the one hand, this represents the ability to physically reach many of these services, which are located in the center of the city, due to their proximity, and on the other hand indicates a relational need that may be lacking in the personal domain but that is reflected in the use of public and private services.

As expected, content and innovation mobility, requiring specific technical skills, appears less widespread throughout the territory. The citizens who move more proactively through the network seem to reside mostly in the northern neighborhoods of the city between Vila de Gràcia and Vallcarca, with an enclave in the neighborhood of Horta, the neighborhoods of the northwest axis and some of the neighborhoods of the district of Ciutat Vella (Barri Gótic and Raval) and excluding the 22@ district (the so-called technological district), suggesting that the workers employed in the technological sector could come from some of these neighborhoods.

The map in Figure 4 represents the average number of displacements per 1000 inhabitants in Barcelona during the COVID-19 national lockdown. The analysis, based on the study of the mobility of the population during the period of the state of alert [64], invites some reflections.

Firstly, the sudden immobility of the neighborhoods in the old town stands out. From a digital point of view, they were previously among the most mobile, especially in terms of remote communication, but they have now become almost totally physically immobile territories. The dynamics are mirrored by the reverse situation in the neighborhoods of Ciutadella and Parc i la Llacuna del Poblenou, ranked highest in the Digital Mobility Index and with between 0.12 and 0.70 displacements per 100,000 inhabitants during the lockdown, as well as the neighborhoods of the old town itself, which move from a high ranking to the first displacement category. This has highlighted the economic monoculture linked almost exclusively to tourism, a sector that nowadays is particularly linked to technology due to the fact that "the ubiquity of computer systems and the availability of the internet have provided unhindered access to consumers of tourism services and the deployment of mobile technology has fundamentally transformed tourism offerings" [65]. In fact, despite the strategic and operational dimensions of ICTs for tourism strategy [66], technologies currently support the entire range of internal and external communications and processes [67], triggering a complete paradigm shift in the hospitality and tourism industry. 


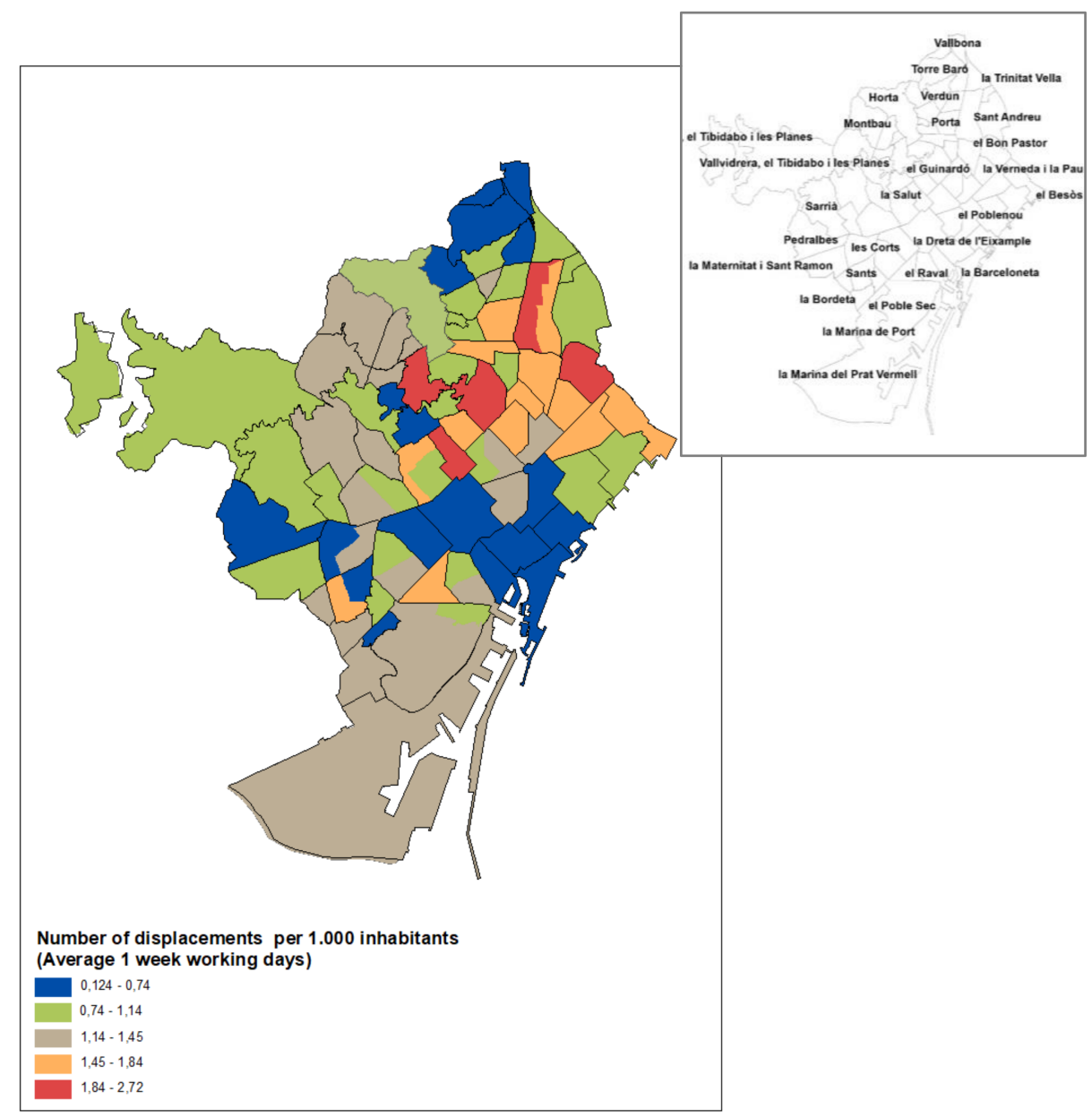

Figure 4. Physical mobility during Covid-19 outbreak in March 2020, Barcelona City.

Additional reflections are provided by the areas of El Coll, La Salut, Vallcarca, and the most central part of the Gràcia neighborhood, other top-ranked digital mobility territories that are almost totally immobilized. The entire northwest sector (high in the Digital Mobility Index) is immobilized (values corresponding to the lower categories), and the digital enclave of Horta (high in the Digital Mobility Index) is also not very mobile, which is significant compared to the surrounding neighborhoods. In fact, this area is characterized by different socio-economic situations; the five neighborhoods at the extreme north-east correspond to the districts of Nou Barris (Ciutat Meridiana, Les Roquetes, Torre Baró, La Trinitat Nova, and Vallbona), where the risk of poverty has increased compared to the city center, and other areas where it has reduced [68]. This explains not only the presence of a very low level of computerization but also a labor immobility clearly not supported by a technological substitution as evidenced by the lack of displacements during the lockdown. The minimum values of the mobility index of the neighborhoods in the northwest of the Horta enclave, partly explained by the older proportion of the population [69], are however complemented by an average level of mobility experienced during the lockdown. The more middle-class social composition of this set of neighborhoods, despite presenting an important digital divide with respect to the city, has predictably kept a working population active and engaged in its commuting obligations regardless of the lockdown, and therefore there is a lower risk of social exclusion.

In contrast, the neighborhood of Horta seems to have replaced physical mobility with digital mobility, possibly linked to the top ranking that this district has achieved in content and innovation mobility skills, which suggests that the neighborhood may host an interesting proportion of the population dedicated to the high-tech sector. 


\section{Discussion}

The advent of digital technologies involves the creation of new kinds of mobile life, new kinds of sociality, and new ways of relating to the self and others. The latest studies by theorists from different disciplines analyze the bidirectional relationship which links mobilities to digital technology as enabling infrastructure for human mobilities on a large and local scale [12]; as multiplier agent people's mobile practices [70] and as an articulating factor of social, physical, mental, and financial relations [21].

However, today more than ever, the debate invites us to consider the extent to which and how mobilities can be fully replaced by digital media through embodiment into the virtual. The immobility caused by COVID-19, partially analyzed here, has certainly underlined that those who used to move the most physically are now those who move the least, replacing most of their activities with virtual ones since their mobile lifestyle never fully connected them with the surrounding territory, placing them on an almost self-sufficient technological island. The typically post-structuralist deterritorializing forces of globalization are translated into the language of media and technology [71], a delocalization of media structures which have nevertheless inherited patterns of uneven geographical development that have been systematically reworked at various spatial scale $[72,73]$.

The mobility enabled by technology responds to situations of socio-economic imbalance, providing a relatively unequal image of the city of Barcelona in terms of usage that is transformed into opportunities and, in turn, what can be achieved with them (life chances), "The problem, however, is not the potential of the technology, but the ways in which it comes to be embedded in societies. Potential can be realized, or can be stultified and atrophy. What happens depends upon the ways in which the technology is developed and implemented, the social uses to which it is put and the degree to which it is diffused throughout society" [74]. In our case in particular, what can be achieved is related to how far you can go (shopping in a downtown store, seeing a friend in New York, or closing a deal in China). As discussed in the preceding sections, those who move the most have access to more opportunities. This creates a vicious circle in which this section of the population gains evermore opportunities to move precisely because they have done so previously, having seeded the global field with harvestable connections which fit their individual needs over time. This is the figure of the networker proposed by Boltanski and Chiapello as "mobile, streamlined, possessed of the art of establishing and maintaining numerous diverse, enriching connections, and of the ability to extend networks" [20]. In this sense the hypothesis of a deepening long-term digital divide in which the normalization curve theorized by Norris [75] tends toward a stratification model prevails, providing a scenario in which groups that are already well networked via traditional forms will maintain their edge in the digital economy.

In light of the above, strictly virtual mobilities are becoming more and more relevant, something closely linked to the physical mobilities enabled by digital. Therefore, territories that are technologically weak resulting from the lack of infrastructure (see infrastructure directly linked to mobility), lack of skills, an aging population and low population turnover have a subordinate position in a community [76], and are at risk of being left out of the geographical reshaping process by techno-mobilities.

Technology as an attempt to transcend physical limitations turns human beings immanent with respect to mobility, which has become an intrinsic characteristic of the subject itself. Understanding technology not as an external agent but as the integrated part of a human being's own immanence has brought the evolution of the concepts of transcendence and immanence-which were once opposed-closer together, drawing an uncertain boundary between the "closed" and the intimate in time and space, and the "open" and public in these same categories. However, this evolution is not perfectly horizontal and universal because there are disparities in the access to technology and consequently mobility produced by different factors (geographic, social, economic, etc.). In 
other words, this new form of "power" reproduces, to some extent, limitations to access that are both subjective and social.

In short, the quality leap does not cover the entire population and the excluded run the risk of a factual and psychological isolation that may be dramatic and offer little chance of recovery.

\section{Conclusions}

A further extension to the previous approaches to the digital divide is comprised of the process of digital inequalities, with mobility as the starting point. The recent body of research on mobilities has examined the link between social exclusion and mobility [19], and in turn, studies of social exclusion are increasingly taking into account ICT approaches by highlighting the role of information technology in the current notion of social exclusion, which refers not only to poverty but also to problems in various other areas (the employment market, democratic activities, the social welfare system, and social relationships), which are currently indissolubly linked to the usage and consumption of technology.

The literature on the mechanisms of digital inequality sheds light on questions related to a variety of both material and cultural factors e.g., [49,53]. This paper has examined the agency of the digital as embodied practice of mobility explored by using the digital divide enquiry conducted in Barcelona and concentrating on people's usage, and by applying a method of geometric data analysis to the research material collected.

Distinguishing analytically between access [77] and use [78] we considered on the one hand access in terms of socio-economic and background status associated with the degree of autonomy people possess in determining how they use the technology [36] and to predict the territorial possibilities of being mobile, both physically and virtually; and on the other, people's effective performance related to usage $[39,40]$.

We have also focused on material practices of mobility, to prove the potential degree of subalternity between the physical and the virtual and to suggest the neighborhoods' $f$ vocations according to their users' essential forms of mobility.

It is worth highlighting that translating the multifaceted concept of "motility" to empirical ground reduces covering all the definitions and meanings (individual and societal, and active and passive potential mobilities) of the notion discussed by various authors in recent years $[79,80]$. The goal of the analysis indeed was to explore the relationship between potential and practiced mobilities as "two-way road, with potential mobilities paving the road for practiced ones, and vice versa: practiced mobilities shaping future potential ones" [12] (p. 179). This aspect of mobility will feed further research oriented at to argue the interconnectedness between the spatial and the digital as a relevant lens for a deeper and more contextualized analysis of the processes of (re)production of social exclusion in cities.

The analysis has painted an unpublished map of the city of Barcelona, which only partly follows the more "well-known" geographic patterns of the city (e.g., high and low income, central and peripheral, and tourist and non-tourist neighborhoods) showing the multifaceted character of technology in its adaptation to the territories. Indeed, according to the analysis, it is not only the economic level of a neighborhood that determines its inclination to be digitally mobile; factors such as the level of immigration or age also have a strong impact on opening the technological doors and, through the digital medium, putting on the "hypermobility" map areas of the city that would otherwise probably be more "immobile" both due to their location and their economies.

Furthermore, emphasis is placed not on the economy but on the economies, emphasizing that despite their capabilities, the territories of the city have different economic vocations and that some require more technological resources and qualified human capital than others for their subsistence. These are directly linked to the ICT economy (see the cases of the city's tourist neighborhoods). 
To summarize, the little evidence we have is equivocal with respect to social inequality in the use of mobility-related technologies, but suggests that for some purposes at least, use would be more equally distributed in a city in which technology plays a relevant role.

Funding: This research was funded by SMARTDEST project EU-funded H2020 under the grant agreement number 870753 .

Data Availability Statement: The data regarding this study has been securely stored following research integrity and data management rules; the corresponding author can provide them with needs.

Conflicts of Interest: The author declares no conflict of interest.

\section{References}

1. Gunkel, D.J. Second thoughts: Toward a critique of the digital divide. New Media Soc. 2003, 5, 499-522. [CrossRef]

2. Van Dijk, J.; Hacker, K. The digital divide as a complex and dynamic phenomenon. Inf. Soc. 2003, 19, 315-326. [CrossRef]

3. OECD. Understanding the Digital Divide; OECD Publications: Washington, DC, USA, 2001.

4. Van Deursen, A.J.; Bolle, C.L.; Hegner, S.M.; Kommers, P.A. Modeling habitual and addictive smartphone behavior: The role of smartphone usage types, emotional intelligence, social stress, self-regulation, age, and gender. Comput. Hum. Behav. 2015, 45, 411-420. [CrossRef]

5. Alizadeh, T.; Farid, R. Political economy of telecommunication infrastructure: An investigation of the National Broadband Network early rollout and pork barrel politics in Australia. Telecommun. Policy 2017, 41, 242-252. [CrossRef]

6. Urry, J. Sociology beyond Society: Mobilities for the Twenty-First Century; Routledge: London, UK, 2000.

7. Cresswell, T. On the Move: Mobility in the Modern Western World; Taylor and Francis: New York, NY, USA, 2006.

8. Kaufmann, V.; Bergman, M.M.; Joye, D. Motility: Mobility as capital. Int. J. Urban Reg. Res. 2004, 28, 745-756. [CrossRef]

9. Kellerman, A. Potential mobilities. Mobilities 2012, 7, 171-183. [CrossRef]

10. Urry, J. Mobile sociology. Br. J. Sociol. 2000, 51, 185-203. [CrossRef]

11. Larsen, J.; Axhausen, K.W.; Urry, J. Geographies of social networks: Meetings, travel and communications. Mobilities 2006, 1, 261-283. [CrossRef]

12. Hannam, K.; Sheller, M.; Urry, J. Mobilities, immobilities and moorings. Mobilities 2006, 1, 1-22. [CrossRef]

13. Sheller, M.; Urry, J. The new mobilities paradigm. Environ. Plan. A 2006, 38, 207-226. [CrossRef]

14. Castells, M. Globalisation, networking, urbanisation: Reflections on the spatial dynamics of the information age. Urban Stud. 2010, 47, 2737-2745. [CrossRef]

15. Carrasco, J.A.; Hogan, B.; Wellman, B.; Miller, E.J. Collecting social network data to study social activity-travel behavior: An egocentric approach. Environ. Plan. B Plan. Des. 2008, 35, 961-980. [CrossRef]

16. Mok, D.; Wellman, B.; Carrasco, J. Does distance matter in the age of the internet? Urban Stud. 2010, 47, 2747-2783. [CrossRef]

17. Taipale, S. The dimensions of mobilities: The spatial relationships between corporeal and digital mobilities. Soc. Sci. Res. 2014, 43, 157-167. [CrossRef]

18. Williams, A.; Anderson, K.; Dourish, P. Anchored mobilities: Mobile technology and transnational migration. In Proceedings of the 7th ACM Conference on Designing Interactive Systems, Cape Town, South Africa, 25-27 February 2008 ; pp. 323-332.

19. Shelton, T.; Zook, M.; Wiig, A. The 'actually existing smart city'. Camb. J. Reg. Econ. Soc. 2015, 8, 13-25. [CrossRef]

20. Boltanski, L.; Chiapello, E. The New Spirit of Capitalism; Verso: London, UK, 2007.

21. Caletrío, J. Global elites, privilege and mobilities in post-organized capitalism. Theory Cult. Soc. 2012, 29, 135-149. [CrossRef]

22. Cass, N.; Shove, E.; Urry, J. Social exclusion, mobility and access. Sociol. Rev. 2005, 53, 539-555. [CrossRef]

23. Freudendal-Pedersen, M.; Kesselring, S. What is the urban without physical mobilities? COVID-19-induced immobility in the mobile risk society. Mobilities 2021, 16, 81-95. [CrossRef]

24. Elliott, A.; Urry, J. Mobile Lives; Taylor and Francis: New York, NY, USA, 2010.

25. Brandtzæg, P.B. Towards a unified Media-User Typology (MUT): A meta-analysis and review of the research literature on media-user typologies. Comput. Hum. Behav. 2010, 26, 940-956. [CrossRef]

26. Ortega Egea, J.M.; Menéndez, M.R.; González, M.V.R. Diffusion and usage patterns of Internet services in the European Union. Inf. Res. 2007, 12, 302.

27. Livingstone, S.; Helsper, E. Gradations in digital inclusion: Children, young people and the digital divide. New Media Soc. 2007, 9, 671-696. [CrossRef]

28. Kalmus, V.; Realo, A.; Siibak, A. Motives for Internet use and their relationships with personality traits and socio-demographic factors. Trames J. Humanit. Soc. Sci. 2011, 15, 385. [CrossRef]

29. Stanley, L.D. Beyond access: Psychological barriers to computer literacy. Inf. Soc. 2003, 19, 407-416. [CrossRef]

30. Mobile World Capital. Available online: https://mobileworldcapital.com/escletxa-digital/index_cas.php\#firstPage (accessed on 11 November 2020).

31. Büscher, M.; Urry, J. Mobile methods and the empirical. Eur. J. Soc. Theory 2009, 12, 99-116. [CrossRef]

32. Jain, J. Bypassing and WAPing: Reconfiguring time-tables for 'real-time' mobility. In Mobile Technologies of the City; Sheller, M., Urry, J., Eds.; Routledge: London, UK, 2006. 
33. Morley, D. Home Territories: Media, Mobility and Identity; Routledge: London, UK, 2002.

34. Townsend, A.M. Life in the real-time city: Mobile telephones and urban metabolism. J. Urban Technol. 2000, 7, 85-104. [CrossRef]

35. Lanier, J. You Are Not a Gadget; Allen Lane: London, UK, 2010.

36. Athique, A. Post-industrial Development and the New Leisure Economy. In Globalisation and the Challenges of Development in Contemporary India; Venkateswar, S., Bandyopadhyay, S., Eds.; Springer: Singapore, 2016; pp. 61-76.

37. Heinrich, C.; Pennington, R.R.; Kuiper, R. Virtual case studies in the classroom improve student knowledge. Clin. Simul. Nurs. 2012, 8, e353-e361. [CrossRef]

38. Gitlin, T. The Whole World Is Watching: Mass Media in the Making and Unmaking of the New Left; University of California Press: Los Angeles, CA, USA, 2003.

39. Jenkins, H. Convergence Culture; New York University Press: New York, NY, USA, 2006.

40. Schradie, J. The digital production gap: The digital divide and Web 2.0 collide. Poetics 2011, 39, 145-168. [CrossRef]

41. Correa, T. The participation divide among "online experts". J. Comput. Mediat. Commun. 2010, 16, 71-92. [CrossRef]

42. Hargittai, E.; Walejko, G. The participation divide. Inf. Commun. Soc. 2008, 11, 239-256. [CrossRef]

43. Mossberger, K.; Tolbert, C.J.; Stansbury, M. Virtual Inequality: Beyond the Digital Divide; Georgetown University Press: Washington, DC, USA, 2003.

44. Van Deursen, A.; Van Dijk, J. Internet skills and the digital divide. New Media Soc. 2011, 13, 893-911. [CrossRef]

45. Ndou, V. E-Government for developing countries: Opportunities and challenges. Electron. J. Inf. Syst. Dev. Ctries. 2004, 18, 1-24. [CrossRef]

46. Luke, A.; Sefton-Green, J.; Graham, P.; Kellner, D.; Ladwig, J. Digital ethics, political economy, and the curriculum: This changes everything. In Handbook of Writing, Literacies, and Education in Digital Cultures; Routledge: New York, NY, USA, 2018 ; pp. 251-262.

47. Ajuntament de Barcelona. Available online: https://ajuntament.barcelona.cat/estadistica/angles/index.htm (accessed on 11 November 2020).

48. Primo Braga, C.A.; Kenny, C.; Qiang, C.; Crisafulli, D.; Di Martino, D.; Eskinazi, R.; Schware, R.; Kerr-Smith, W. The Networking Revolution: Opportunities and Challenges for Developing Countries. Global Information and Communication Technologies Department: The World Bank Group. 2000. Available online: http://www.infodev.org/library/WorkingPapers/ NetworkingRevolution.pdfURL (accessed on 14 May 2021).

49. Brandtzæg, P.B.; Heim, J.; Karahasanović, A. Understanding the new digital divide-A typology of Internet users in Europe. Int. J. Hum. Comput. 2011, 69, 123-138. [CrossRef]

50. Chen, W.; Wellman, B. Minding the cyber-gap: The Internet and social inequality. In The Blackwell Companion to Social Inequalities; Wiley: Hoboken, NJ, USA, 2005; pp. 523-545.

51. DiMaggio, P.; Hargittai, E.; Celeste, C.; Shafer, S. From Unequal Access to Differentiated Use: A Literature Review and Agenda for Research on Digital Inequality; Princeton Press: Princeton, NJ, USA, 2003.

52. Hargittai, E.; Hinnant, A. Digital Inequality: Differences in Young Adults' Use of the Internet. Commun. Res. 2008, 35, 602-621. [CrossRef]

53. Selwyn, N. Reconsidering political and popular understandings of the digital divide. New Media Soc. 2004, 6, 341-362. [CrossRef]

54. Zillien, N.; Hargittai, E. Digital distinction: Status-specific types of internet usage. Soc. Sci. Q. 2009, 90, 274-291. [CrossRef]

55. Van Deursen, A.J.; Van Dijk, J.A. The first-level digital divide shifts from inequalities in physical access to inequalities in material access. New Media Soc. 2019, 21, 354-375. [CrossRef] [PubMed]

56. Katz, J.E.; Rice, R.E. Social Consequences of Internet Use: Access, Involvement, and Interaction; MIT Press: Cambridge, MA, USA, 2002.

57. Singh, J. Collaborative networks as determinants of knowledge diffusion patterns. Manag. Sci. 2005, 51, 756-770. [CrossRef]

58. David, A.; Terstriep, J.; Sospiro, P.; Scibè, E. Migrants' Digital Knowledge Flows: How Digital Transformation Shapes Social Behaviour. Available online: https:/ / www.econstor.eu/handle/10419/197992 (accessed on 25 November 2020).

59. Pries, L. Transnationale Migration. Soziale Welt Sonderband 1997, 12, 372.

60. Christiansen, C. News Media Consumption among Immigrants in Europe the Relevance of Diaspora. Ethnicities 2004, 4, 185-207. [CrossRef]

61. Georgiou, M. Diaspora, Identity and the Media: Diasporic Transnationalism and Mediated Spatialities; Hampton Press: New York, NY, USA, 2006.

62. Mansilla López, J.A. Movimientos sociales y apropiaciones colectivas en la Barcelona post-15M: El papel de la Assemblea Social del Poblenou. Etnográfica. Revista Centro Rede Investigação Antropologia 2015, 19, 77-97. [CrossRef]

63. López Palomeque, F. Barcelona, de ciudad con turismo a ciudad turística: Notas sobre un proceso complejo e inacabado. Documents d'Anàlisi Geográfica 2015, 61, 483-506.

64. National Institute of Statistics. Available online: https://www.ine.es/en/experimental/movilidad/experimental_em1_en.htm (accessed on 25 November 2020).

65. Ukpabi, D.C.; Karjaluoto, H. Consumers' acceptance of information and communications technology in tourism: A review. Telemat. Inform. 2017, 34, 618-644. [CrossRef]

66. Law, R.; Jogaratnam, G. A study of hotel information technology applications. Int. J. Contemp. Hosp. Manag. 2005, 17, 170-180. [CrossRef]

67. Buhalis, D. eTourism: Information Technology for Strategic Tourism Management; Pearson Education: London, UK, 2003. 
68. Porcel López, S.; Navarro-Varas, L.; Antón-Alonso, F.; Cruz, I. La suburbanització de la pobresa com a efecte metropolità de la gentrificació: El cas de Barcelona. Papers Regió Metropolitana Barcelona Territori Estratègies Planejament 2018, 60, 94-113.

69. López-Gay, A. Barcelona's got talent: Migration, residential change and socioeconomic polarisation. Studies 2016, 2011, 14. [CrossRef]

70. Shove, E. Rushing around: Coordination, Mobility and Inequality. Available online: https://www.lancaster.ac.uk/staff/shove/ choreography/rushingaround.pdf (accessed on 25 November 2020).

71. Lévy, P. Cyberculture; University of Minnesota Press: Minneapolis, MN, USA, 2001.

72. Brenner, N. New State Spaces: Urban Governance and the Rescaling of Statehood; Oxford University Press: Oxford, UK, 2004.

73. Castells, M. Toward a sociology of the network society. Contemp. Sociol. 2000, 29, 693-699. [CrossRef]

74. Sparks, C. The Distribution of Online Resources and the Democratic Potential of the Internet. In Cultural, Economic and Policy Foundations for Media Openness and Diversity in East and West; Van Cuilenburg, J., van der Wurff, R., Eds.; Het Spinhuis: Amsterdam, The Netherlands, 2000; pp. 229-254.

75. Norris, P. A Virtuous Circle: Political Communications in Postindustrial Societies; Cambridge University Press: Cambridge, UK, 2000.

76. Nadiruzzaman, M.; Wrathall, D. Participatory exclusion-Cyclone Sidr and its aftermath. Geoforum 2015, 64, 196-204. [CrossRef]

77. DiMaggio, P.; Hargittai, E. From the 'Digital Divide'to 'Digital Inequality': Studying Internet Use as Penetration Increases; Working Paper 15; Center for Arts and Cultural Policy Studies, Woodrow Wilson School, Princeton University: Princeton, NJ, USA, 2001.

78. Hargittai, E. The digital divide and what to do about it. In New Economy Handbook; Academic Press: San Diego, CA, USA, 2003; pp. 821-839.

79. Kellerman, A. Personal Mobilities; Routledge: London, UK, 2006.

80. Adey, P. Mobility; Routledge: London, UK, 2010. 